\title{
Presentation De relatione
}

\author{
Maria Cabré Duran \\ Alexander Fidora \\ ICREA - Universitat Autònoma de Barcelona \\ mariacabre1706@gmail.com \\ alexander.fidora@icrea.cat
}

The history of philosophy has for many centuries neglected the concept of relation, which was conceived by many philosophers as a "secondary category". In the traditional account that goes back to Aristotle, the category of relation (pros $t i$ ) is not constitutive of reality but rather presupposes it; accordingly, relations are described as accidents which add very little, if anything, to reality. It comes as no surprise, therefore, that Thomas Aquinas referred to the category of relation as an "ens minimum", i.e. "the lowest form of being" (Super Sent. I, d. 26, q. 2, a. 2, ad 2).

One of the undisputable achievements of the philosophical and theological discourse of the Middle Ages is to have rescued the category of relation from oblivion. Revisiting the issue, medieval philosophers and theologians put forward a considerably richer theory of relation than their predecessors did. While fundamental impulses for this reassessment came from Trinitarian speculation, which posited substantial relations between the three persons in God, these efforts eventually led to a completely new appreciation of the concept of relation which challenged the logical and ontological status of this category in particular, and of the ten categories in general. Thus, one finds perspicacious discussions de relatione not only in commentaries on the Sentences, but also in medieval commentaries on Categories (c. 7), Physics (V, 2), Metaphysics (V, 15), in Quaestiones disputatae and Quaestiones quodlibetales, as well as in specific treatises such as Robert Kilwardby's De natura relationis. Such was the prominence of relation towards the end of the thirteenth century that Albert the Great would state in his late Summa theologiae that philosophers had always argued on the subject: "inter philosophos semper fuit disputatio de relativis" (I, p. 13, q. 12).

This issue of Enrahonar brings together six contributions which shed new light on the development of the theory of relation from the early Middle Ages through to the High Scholastic period, taking into account logical and onto- 
logical expositions on the subject, as well as deployment of the concept of relation in other contexts, such as practical philosophy. In political theory, in particular, relations of power were at the very centre of some of the most heated debates during the thirteenth and fourteenth centuries.

The first article by María Jesús Soto-Bruna (Universidad de Navarra) focuses on John Scottus Eriugena and his treatise De relatione in the Periphyseon. She shows that Eriugena played a key role in re-framing reflections about the category of relation which he understood to be the very condition of the multiplicity that constitutes reality. Tightly linking, as he does, relation to the First Principle - which is at the origin of the hierarchically ordered chain of being - the former becomes a fundamental part of Eriugena's interpretation of reality as a whole. His approach was highly influential during the Middle Ages, as Soto-Bruna illustrates with the example of the twelfth-century philosopher from Toledo, Dominicus Gundissalinus, and his cosmological treatises De unitate et uno and De processione mundi.

John Marenbon (University of Cambridge) addresses two central claims of the standard interpretation of how medieval authors understood the category of relation, and shows that the discussions on the subject during the Middle Ages were much more nuanced than the traditional account reflects. The first of the claims that he revisits contends that relations were described as monadic accidents. Marenbon shows that at least some medieval authors, such as John Scottus Eriugena, were very much aware of the polyadic nature of relations; that is, they acknowledged that relations are a feature not merely of one item, but embrace at least two relata. The second of the claims that Marenbon tackles concerns the ontological status of relations: while it is true that for many medieval authors relations were real things, there are significant exceptions. In the glosses on Boethius and Martianus Capella, for example, and also in the works of authors such as Peter Abelard, Marenbon observes the tendency to interpret relations from a linguistic rather than ontological point of view.

These two papers on the logical and ontological aspects of medieval theories of relation are complemented by the article by José Antônio de C.R. de Souza (Universidade Federal de Goiás). De Souza draws attention to a political dialogue from the end of the thirteenth century, the Disputatio inter clericum et militem. Written in response to Pope Boniface VIII's Clericis laicos of 1296 , this anonymous work argues in favour of a clear-cut separation of the competences of imperial and ecclesiastical powers, sustaining the secular sphere by securing its autonomy. While the text draws on common sources of the political discourse of its time, such as Aristotle's Politics and Roman Law, its dialogic form distinguishes it among the rich literature on political philosophy of its day.

Hans Daiber (Goethe-Universität Frankfurt) broadens the scope of the papers in this volume in yet another direction, namely that of Arabic philosophy. In his succinct history of the category of relation from al-Kindī and his student Aḥmad Ibn aṭ-Ṭayyib as-Saraȟsī, to al-Fārābī, Ibn Sīnā, al-Ghazālī, Ibn Rušd, Ibn 'Arabī and Ibn Sab'īn, he draws the general lines along which 
the theory of relations evolved in the Arabic tradition. In so doing, he identifies striking parallels in the developments of both the Latin and the Arabic Middle Ages, such as the connection between the theory of relation and a dynamic ontology.

This very connection is at the centre of Ramon Llull's philosophical and theological project. Commemorating his seventh centenary, two articles on Llull conclude this issue of Enrahonar. Ruedi Imbach (Université de la Sorbonne) raises the historiographical question of how the relation of a philosopher, such as Llull, to a certain place and a particular time can be considered relevant for his or her philosophy, which as such transcends space and time. He does this by comparing the teachings of three philosophers, namely Llull, Meister Eckhart and Dante, who coincided in Paris during the years 1310-11. While they do not mention each other in their respective works, Imbach reveals striking commonalities in their approach to philosophy which range from the use of the vernacular to their solutions to the faith-reason controversy.

Alexander Fidora (ICREA - Universitat Autònoma de Barcelona) continues with this much debated topic in the history of Lullism, that is, the specific relation that Llull establishes between faith and reason. As Fidora shows in analyzing Llull's analogy of the relation of faith and reason in terms of oil and water, one can argue that for him this relation was more than purely accidental. In the concrete history of mankind, sub statu gratiae, that is, both are intrinsically related to each other to such an extent that their relation may be described as essential.

Preliminary versions of the six papers were read at the $7^{\text {th }}$ International Ibero-American Congress of the Spanish Society of Medieval Philosophy on the Occasion of Ramon Llull's Seventh Centenary (1315/1316), that was held November 14-16, 2016 at the Universitat Autònoma de Barcelona and the Facultat de Teologia de Catalunya. The organizers of the congress, Maria Cabré Duran, Alexander Fidora and Jaume Mensa i Valls, wish to express their gratitude to the Spanish Society of Medieval Philosophy (SOFIME) and its members, as well as to the authors of this volume, who thoroughly revised their papers for the present publication. Related articles dealing with further aspects of the medieval theory of relation will appear in a supplementary volume in the near future.

One of our contributors, our dear friend and colleague José Antônio de C.R. de Souza, is no longer among us. To his memory we dedicate this issue of ENRAHONAR. 